
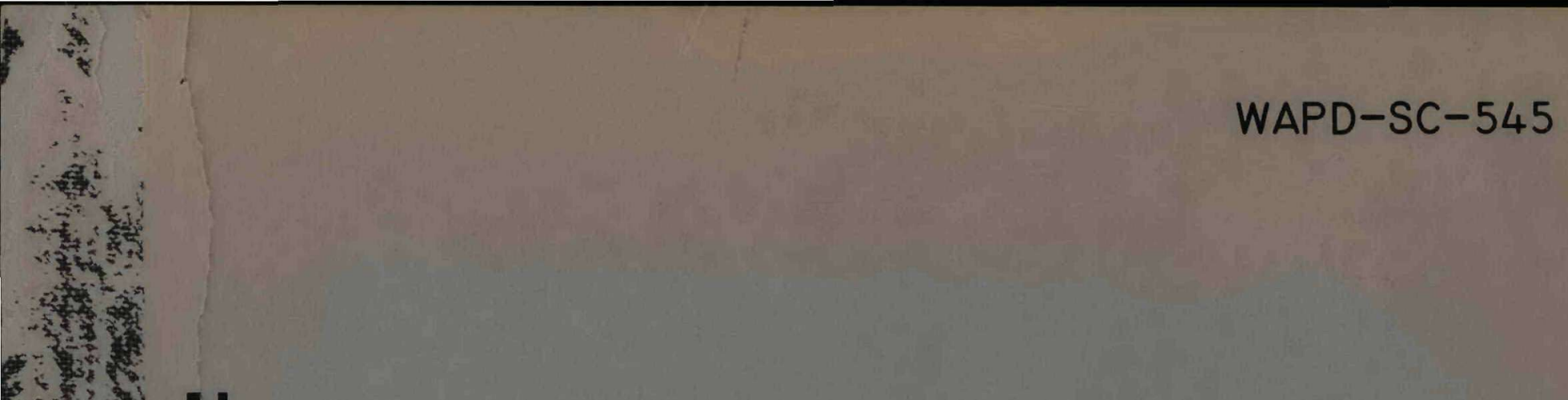

然

\title{
HYDROGEN FLAMMABILITY DATA AND APPLICATION TO PWR LOSS-OF-COOLANT ACCIDENT
}

CONTRACT AT-11-1-GEN-14

BETTIS PLANT PITTSBURGH, PENNSYLVANIA

Operafed for the $\left(\mathbf{W}_{0}^{\circ}\right.$ U.S. ATOMIC ENERGY COMMISSION bY WESTINGHOUSE ELECTRIC CORPORATION 


\section{DISCLAIMER}

This report was prepared as an account of work sponsored by an agency of the United States Government. Neither the United States Government nor any agency Thereof, nor any of their employees, makes any warranty, express or implied, or assumes any legal liability or responsibility for the accuracy, completeness, or usefulness of any information, apparatus, product, or process disclosed, or represents that its use would not infringe privately owned rights. Reference herein to any specific commercial product, process, or service by trade name, trademark, manufacturer, or otherwise does not necessarily constitute or imply its endorsement, recommendation, or favoring by the United States Government or any agency thereof. The views and opinions of authors expressed herein do not necessarily state or reflect those of the United States Government or any agency thereof. 


\section{DISCLAIMER}

Portions of this document may be illegible in electronic image products. Images are produced from the best available original document. 
WA PD-SC-545

Reactors - Power

(TID-4500, 13th Edition)

HYIFOGEN FLAMMABILITY DATA

AND AFPLICATION TO PWR LOSS-OF-COOLANI ACCIDENT

Dr. Z. M. Shapiro

T. R. Moffette

September 1957

Contract $\left.A I^{\prime}-1\right]-1-G E N-14$

Information Category

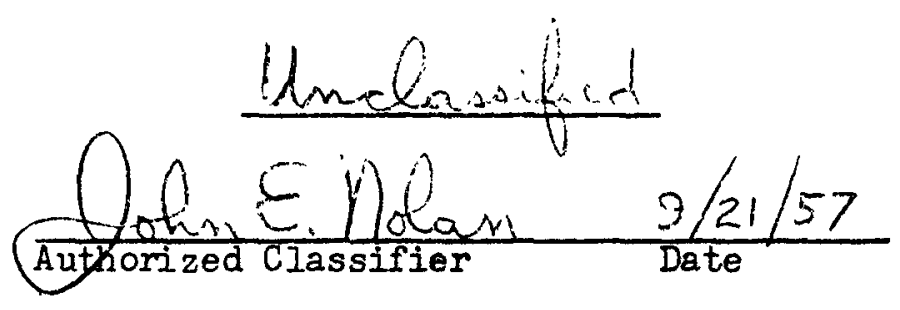

H.00

Printed in USA. Price Available from the Office of Technical Services, Department of Commerce, Washington 25, D.C.

BETTIS PIANT

PITT SBURGH, FA.

Operated for the U. S. Atomic Energy Commission by Westinghouse Electric Corporation 
WA PD-SC-545

\section{FOREWARD}

This document has been submitted to the Advisory Committee on Reactor Safeguards to the Atomic Energy Commission for use in evaluating the safety of the PWR Reactor Plant (Shippingport Atomic Power Station). As such, this information is supplemental to the PWR Hazards Sumnary Report, WAPD-SC-54I.

\section{LEGAL NOTICE}

This report was prepared as an account of Government sponsored work. Neither the United States, nor the Commission, nor any person acting on behalf of the Commission:

A. Makes any warranty or representation, express or implied, with respect to the accuracy, completeness, or usefulness of the information contained in the report, or that the use of any information, apparatus, method, or process disclosed in this report may not infringe privately owned rights; or

B. Assumes any liabilities with respect to the use of, or for damages resulting from the use of any information, apparatus, method, or process disclosed in this report.

As used in the above, "person acting on behalf of the Commission" includes any employee or contractor of the Commission to the extent that such employee or contractor prepares, handles or distributes, or provides access to, any information pursuant to his employment or contract with the Commission. 
Aberdeen Proving Ground

Nico Froducts, Inc.

Arsonne National Laboratery

Armed Forces Special Woapon Project, Washington

Armnd Services Technical Information Agency, Dayton

$\Lambda$ tiantic lilect

Atomic Energy Commission, Patent Branch

Atomic Enorgy Commission, Technical Library

$\Lambda$ tomics Intornational

Battelle Meinorial Institute

Bettis Plant

Brookhaven National Laboratory

Brush Reryldium Company

Bureau of Medicine and Surgery

Bureau of Ships (Code 590)

Chicago Patent Group

Combustion Encineering, Inc.

Consolidated Vultee Aircraft Corporation

Convair-General Dymamics

Defence Research Member

Defirtment of Food Technology (MIT)

Department of Navy (Code 422)

Department of the Army, G-2

Division of Raw Materials, Denver

Dow Chemical Company (Rocky Flats)

Du Ports de Nemours and Company, Aiken

Du iont de "rmours and Company, Wilmington

Frankford hrsenal

Gerpral Electric Company (ANPP)

General Electric Company, Richland

General Nuclear Engineering Corporation

Iowa State College

Kirtland $\Lambda$ ir Force Base

Knolls Atomic Power Iaboratory

Lockheed Aircraft Corporation (Bauer)

Ios Alamos Scientific Laboratory

Mallinckrodt Chemical Works

Massachusetts Institute of Technology (Dr. Hardy)

Mound Laboratory

National Advisory Committee for Aeronautics, Cleveland

National Bureau of Standards, Atomic Energy Project

National Bureau of Standards (Library)

National Lead Company, Inc., Winchester

Navai liesearch Laboratory

New York uperations Office .

New York University (Dr. Richtmyer)

Nuclear Development Corporation of America

Nuclear Metals, Inc.

Oak Ridge Institute of Nuclear Studies

Oak lidge National Laboratory

Office of Naval Research 
Distiribution

Fhilitps letrolloum Company

Publtc Health Service

RAND Corporation

Sandia Corpuration

Sicnal Corps Center

Sylvanta Flectric lroducts, Inc.

Technical Operations, Incorporated

Union Carbide Nuclear Company ( $\mathrm{K}-25$ Plant)

United Aircrast Corporation

U. S. Geolocical Survey, Denver

U. S. Naval Urdnance Laboratory

U. S. Naval Postgraduate School

U. S. Naval Radiologjcal Defense Laboratory

U. S. Fatent Orfice

University of California Radiation Lacoratory, Berkeley

University of California Radiation Laboratory, Livermore

University of Rochester, Atomic Energy Project

University of Rochester (Dr. Marshak)

Vitro Engineering Division

Walter Reed $\Lambda$ rmy Medical Center

Watertown Arsenal

Weil, Dr. George L.

Westinghouse Electric Corporation

Technical Information Service Extension, Oak RIdge

Office of Technical Services, Washington

Manager, Fittsburgh Area Office

WA FD Distribution XIV
No. of Coples

6

2

1

1

1

2

2

3

1

2

2

1

1

2

2

1

2

1

1

1

1

2

300

100

29

70 
INTRODUCTION AND SUMMARY............................

I. GENERAL DISCUSSIUN REGARDING THE FLAMMAEILITY UY IIYDROGEN......3

A. Limits of Flammability.........................

B. Conditions for rropagation of Flames in llixtrres of Gases...3

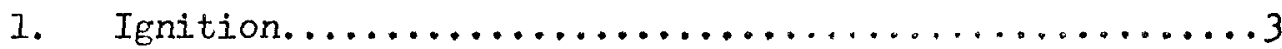

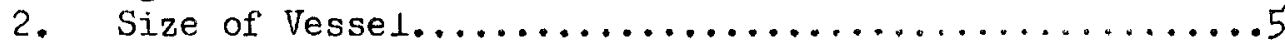

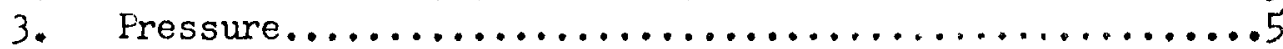

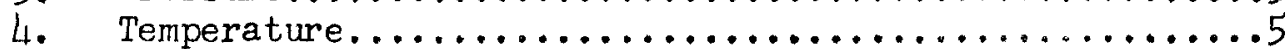

5. Turbulence...........................

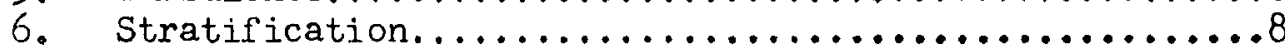

7. Effect of Chemically Inert Substances.............8

8. The limits of Flammability of Hydrogen in Air

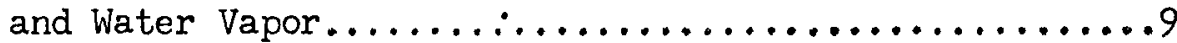

C. Spontaneous Ignition Temperature..................

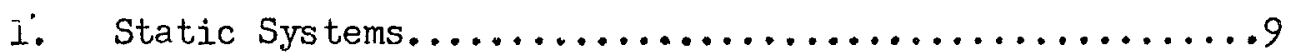

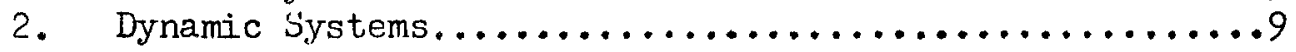

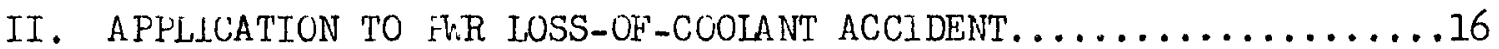

A Combustion of Steam-Hydrogen Mixture Escaping from

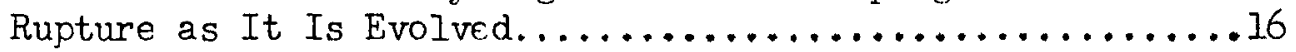

B. Delayed Combustion of Accumulated Hydrogen................ 19

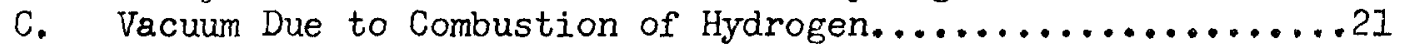


WA PD-SC- 545

\section{LIST OF ILLUSTRATIONS}

Fig. No.

1

2

3

4

5

6

7

8

9

12 of

Ill of
Effect of Pressures above Normal on Flammability Limits of Hydrogen in $\Lambda$ ir

Influence of Temperature on Limits of Flammability of Hydrogen in Air

Flammability Limits of Hydrogen-AirSteam Mixtures

Variation of Minimum Spontaneous Ignition Temperatures (S.I.T.) with Hydrogen Concentration of Hydrogen-Water Vapor-Air Mixtures

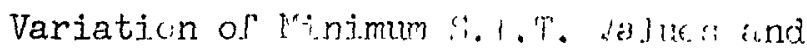
Maximum ramiunion lersmers ith ? ater Vapor Concrntration of Ilydrogen-Water Vapor-Air Mixtures

Variation in the Minimum S.I.T. with Exit Velocity of Ifydrosion

Variation in the Minumum S.I.T. of Hydrogen-Water Vapor Mixtures Flowing into Air

Pressure in Flant Container at'ter Large Rupture of Main Coolant System

Percentage of Metal Reacted Vs. Quantity of $\mathrm{H}_{2}$ Formed

WAFD-SC-544. Temperature of Gas Stream Leaving Reactor Vessel

WA FD-SC-544. Composition of Gas Stream Leaving Reactor Vessel
Westinghouse

Page Neg. No.

$6 \quad 28678-2$

$7 \quad 18678-4$

$13 \quad 18678-3$

14 18678-1

14 18678-1

$15 \quad 18678-5$

$15 \quad 18678-5$

$18 \quad 20204$

$20 \quad 18678-6$

17 20431-12

$17 \quad 20 / 131-14$ 
WA FD-SC -545

\author{
HYDROGEN FLAMMABILITY DATA \\ AND APPLICATION TO FWR LOSS-OF-COOLANT ACCTDFNT
}

By Dr. Z. M. Shapiro and T. R. Moffette

Introduction and Summary

The purpose of this report is: (a) to summarize generalized data on the flammability of hydrogen in steam-air mixtures; and (b), of nrimary importance in FWR Safeguards considerations, to apply the flammability data to the postulated $\mathrm{HR}$ loss-of-coolant accident and to determine the putentual pressure effects on the IVR plant container.*

Other documents** of this series related to lifi Safeguards discuss the possibility and results of a major loss-of-coolant accident in PWR (the Shippingport Atomic Power Station). There it is shown that a zirconium-water (or steam) reaction is a possible result of such an accident, evolving significant quantities of heat and hydrogen. It is therefore necessary to assess the possibility of damage to the PWR plant container due to high pressure resulting from detonation or combustion of hydrogen.

A rupture of the reactor coolant system, causing loss of the primary coolant, is considered to be extremely unlikely. Furthermore, in order for this accident to result in an extensive zirconium-water reaction, with hydrogen and heat release: (1) the rupture of the primary coolant system would have to be located below the level of the core and in the part of the system within the reactor chamber of the reactor plant container; and (2), the rupture size must be sufficiently large so the Safety Injection System cannot replenish the water faster than it escapes from the rupture; and/or (3), the Safety Injection System supplies less than its maximum capacity, or does not function at all.

In the specific application of the general information on hydrogen flammability to the PWR loss-of-coolant accident in this report, it is shown that the hydrogen would probably be evolved from the rupture at such an elevated temperature that spontaneous ignition should occur, preventing a large amount of unburned hydrogen from accumulating. The evolution of hydrogen is

* The PWR reactor plant container is a pressure vessel completely surrounding the reactor, primary coolant system, and major auxiliary systems that contain hot, compreised, radioactive coolant. Its function is to enclose any radioactive matcrial as may be accidentally released, preventing its escape to the outside atmosphere. The container was designed to withstand a $52.8 \mathrm{psig}$ internal pressure, the calculated maximum that would occur due to release of hot-compressed coolant due to a rupture of the reactor coolant system. ** WAPD-SC-54I, "WJR Hazards Summary Report"; WA PD-SC-543, "Zirconium-Water Reaction Data and Application to PWR Loss-of-Coolant Accident"; WAPD-SC-544, "PWR Loss-of-Coolant Accident - Core Meltdown Calculations." 
sufficiently slow so that if the hydrogen is burned as evolved the pressure within the plant container would be raised by only a few psi, at a time when the total pressure would be considerably less than the plant container design pressure.

In the event the hydrogen does not burn as it is evolved, (for example if it should escape from the reactor vessel through a water trap with resultant cooling of the gas) it is unlikely that a detonation would occur. If a uniform mixture of steam, air, and hydrogen is obtained in the plant container, the maximum hydrogen concentration would be below that required for detonation. Therefore, no detonation should occur unless localized pockets of hydrogen concentration occur. Even should such a pocket detonate, it is believed the peak pressure would not exceed the plant container design pressure. 
WA FD-SC-545

I. GENERAL DISCUSSION REGARDING THE FLAMMABILITY OF HYDRUGEN

A. Limits of Flammability

A mixture of flammable gases such as hydrogen and air, or hydrogen and oxygen, may be diluted with one of its constituents or with other gases until it is no longer flammable. The marginal composition at which such 2 mixture will become flamable or non-flammable by a slight change is defined as the "limit of flammability."

A combustible gas mixture generally has two limits of flammability, an upper limit and a lower one. Only when the composition is well between these limits will the gaseous mixture burn or explode. In the case of hydrogenair mixtures, these limits are generaily quoted as $4.1 \%$ and $74 \%$ hydrogen for the lower and upper limits, respectively. The picture is not as clear cut as these figures would lead one to believe, however, since these limits vary greatly depending on whether the mixture is at room temperature or above, and whether it is at atmospheric pressure. Simple quotation of the limits of flammability is also misleading in that these do not indicate the kind of combustion which occurs, i.e., simple burning, explosion, or detonation. In handling explosive mixtures it is obviously desirable to do this in a manner such that the lower limit of flammability will be raised and the upper Limit lowered, and in a manner such that the mixture, if ignited, will not detonate. The factors affecting these limits are discussed more fully in the following section.

\section{B. Conditions for Propagation of Flames in Mixtures of Gases}

1. Ignition

If a source of ignition is brought to the center of a combustible mixture, it would be expected that the flame would tend to travel away from the source uniformly in all directions. This rould probably be the case if it were not for the convection currents set up by the hot, expanded combustion products which cause an upward movement of the ases. In the case of limit mixtures, the rate of propagation of the flame is less than the rate of rise of the flanmable mixture due to convection currents. Under these conditions the flame cannot move downward. A similar condition holds true in the case of horizontal flame propagation, the limits for which lie between those for upward and downward propagation. Accordingly, the range of mixtures between the limits for upward and horizontal propagation will propagate flame upward but not horizontally or downward, whereas, the range of mixtures between the limits for horizontal and downward propagation will propagate flame horizontally and upward, but not downward. Thus, when limits of flammability are given it is important to note the direction of flame propagation to which the limits apply. 
WA PD $-S C-545$

The lower flammability limits for hydrogen in air are $4.1 \%$ for upward propagation, 6\% for horizontal propagation and 9\% for downward propagation. Although the upper limits for horizontal and downward propagation are somewhat smaller than the upper limit for upward propagation, these are not we $\perp \perp$ established. Accordingly, all the upper limits are taken as $74 \%$ in order to be on the safe side. In all cases, the above limits apply to gases maintained at atmospheric pressure and saturated with water vapor at room temperature.

Ignition of hydrogen-a1r mixtures, particularly when these mixtures are well within the flammability limits, takes place with an exceedingly small input of energy. A spark having such low energy that it is invisible in a dark room will ignite such a mixture. Common sources of ignition are sparks from electrical equipment, and sparks caused by the discharge of small accumulations of static electrical charges. Even though a mixture is below the limit of flammability, some combustion can be made to occur with a source of sufficient size and intensity. Such flames are not self-propagating, however, and will be extinguished as soon as the source of ignition is removed.

In general, mixtures of hydrogen and air burn with a very pale flame. In the case of the limit mixtures the flames may even be invisible. When mixtures raving compositions close to flammabi. by limits are ignited a ring of flame is formed which breaks up into balls of flame that travel to the top of the test vessel. Unly a fraction of the hyorogen is burned in these cases. As the percentage of hydrogen in a hydrogen-air mixture is increased, however, an increasing amount of the hydrogen present will be burned. A $5.6 \%$ hydrogen mixture, for example, will burn only about 50\% of the hydrogen, and complete combustion rill not occur until the percentage of hydrogen is increased to $10 \%$. Accordingly, as the percentage of hydrogen in mixtures with air is increased from $4.2 \%$ to $10 \%$, the energy released by the combustion increases out of proportion to the increase in the amount oi hydrogen.

As indicated by the flammability limits given above, it is not until the hydrogen concentration in air reaches 9\% that the flame will be propagated downward. This is not to say that hydrogen and air mixtures having Iess than 9\% hydrogen are not dangerous. This depends largely upon the point of ignition. For example, a mixture of hydrogen and air containing $6 \%$ hydrogen, if ignited near the ceiling, would propagate only upward and horizontally until the flame would reach the walls and ceiling where it would be extinguished; whereas the same mixture, if ignited ncar the floor, would propagate throughout the whole roum, reach a mean temperature of $350^{\circ} \mathrm{C}$, and build up a pressure of approximately 1 atm. As the hydrogen concentration increases beyond $9 \%$ not only

* It is interesting to note that despite the fact that the spontaneous ignition temperature of a hydrogen air mixture is $585^{\circ} \mathrm{C}$ and despite the fact that $4.1 \%$ hydrogen air mixture has a flame temperature considerably below this, such a mixture will be self propagating. This phenomenon is attributed to the ability of hydrogen to diffuse into the flame more rapidly than other gases and thus maintain the necessary concentration for flame propagation. 
does the flame propagate in all directions but the rate of propagation increases rapidly. When the concentration of hydrogen in air reaches $19 \%$, the mixture detonates. This condition is particularly severe until the hydrogen concentration in such a mixture exceeds $57 \%$.

\section{Size of Vessel}

Since the propagalion of flame depends upon the transfer of enerry from the burned to the unburned gas, and since in a limit mixture the amount of energy available for transfer is only just enough to propagate the flame, anything that reduces the available energy will affect the limits. Thus, if a vessel has a high surface-to-volume ratio, the effect of cooling by the walls of the vessel becomes appreciable and the flammability limits are narrowed somewhat.

\section{Pressure}

Norma $\downarrow$ variatıons of atmospheric pressure do not affect the limits of flammability anpreciably. However, larger variations in pressure cause effects that are different for 6 ach mixture. Thus it is impossible to generalize. Fortunately, in the case of hydrogen-air mixtures, the range of flammability for downward propagation is narrowed at both limits by moderate increases of pressure above atmospheric. Above $10 \mathrm{~atm}$ and up to $220 \mathrm{~atm}$ however, the upper limit for hydrogen increases. The magnitude of this increase is shown in Fig. 1. In addition to the data given in Fig. 1, a series of experiments performed by Eitner (a) indicate there is no change in the lower limit over a range from 0.5 to $4.0 \mathrm{~atm}$.

\section{Temperature}

To propagate flame, the layer of unburned gas next to the burning layer must be brought up to ignition temperature. If the unburned gas is already above room temperature, less heat need be supplied by the burning gas to bring the adjacent layer up to ignition temperature. Thus the range of flammability is widened at both limits by increasing the temperature of the mixture. In the case of hydrogen-air mixtures, as for most mixtures, there is a straightline relation between the limit of flammability and the initial temperature of the mixture. Thus, at $200^{\circ} \mathrm{C}$ the lower limit for downward propagation of hydrogen-air mixtures decreases to $7.9 \%$ while the upper limit increases to $76 \%$; at $400{ }^{\circ} \mathrm{C}$ the lower limit decreases to $6.3 \%$ while the upper limit increases to $81.5 \%$. The change in the limits of flammability of $\mathrm{H}_{2}$ in air for downward propagation are given in Fig. 2.

(a) Eitner, P. Explosion Limits of Flammable Gases and Vapors, Habilitations - Schrift, Munchen, 1902. 
EFFECT OF HRESSURES ABOVE NORMAL

ON FIAMMABILITY LIMITS OF HYDROGEN IN AIR

EXPERIMENT

- DOWNWATR PROPAGATION; CYLINDER, $37 \times 8 \mathrm{~cm}$

- downward propagation, cylinder

- side of CENTRAL IGNITION; SPHERE, 7.6 CM DIAM.
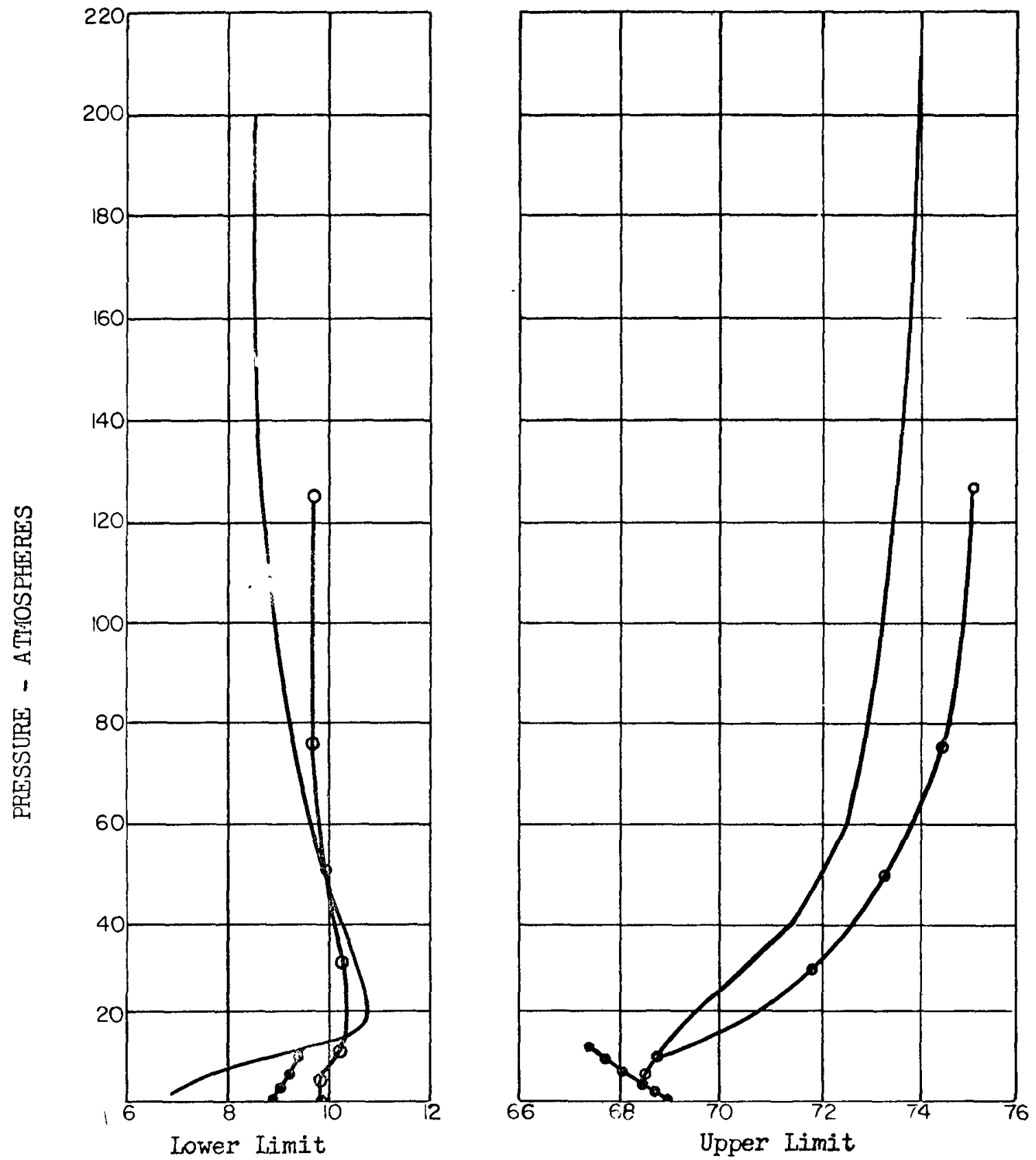

HYDROGEN-FERCENT

FIG. 1

$-6-$ 
INFLUENCE OF TEMPERATURE ON LIMITS OF FLAMMABILITY OF HYDROGEN IN AIR (DOWNWARD PROPAGATION OF FLAME)

A. MAXIMUM AMBIENT TEMPERATURE ATTAINED IN CONTAINER B. AMBIENT IN THE CONTAINER

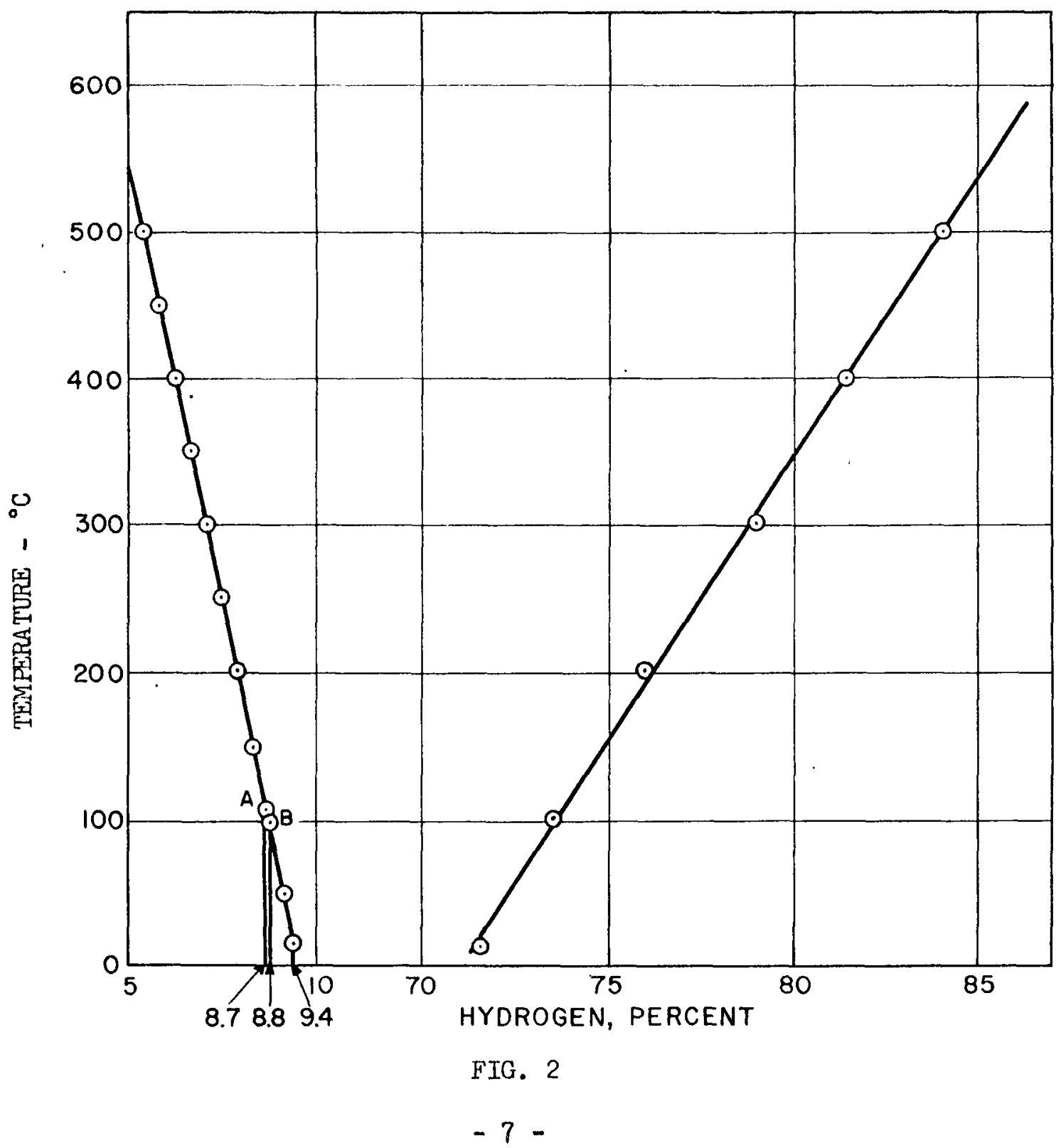


A recent study' of the combined effects of pressure and temperature on the upper and lower limits of flammability of hydrogen-air-water vapor indicate that at 50 and $700 \mathrm{psig}$ and $300^{\circ} \mathrm{F}$ the effect of temperature on widening the flammability limits is counterbalanced by the effect of pressure on narrowing the limits. Thus at $50 \mathrm{psig}$ and $300^{\circ} \mathrm{F}$ the upper and lower limits of flammability for upward propagation are 77 and $5 \mathrm{v} / \mathrm{o} \mathrm{H}_{3}$ respectively, whereas at $100 \mathrm{psig}$ and $300^{\circ} \mathrm{F}$ the upper and lower Limits are 78 and $4 \mathrm{v} / \mathrm{o} \mathrm{H}_{2}$ respectively. As indicated previously, the limits at atmospheric pressure and room temperature are 4.1 and $74 \mathrm{v} / \mathrm{H}_{2}$.

\section{Turbulence}

No observations have been made on the effect of turbulence on the limits of flammability of hydrogen-air mixtures. It has been shown, however, that the lower limits of methane and ethane are reduced somewhat by agitation of the mixture. This effect is expected to be even smaller in the case of hydrogen-air mixtures due to the hisher rate of diffusion of $\mathrm{H}_{2}$ in the atmosphere.

\section{Stratification}

Because hydrogen has a lower density than that of any other gas, sıow leakage of hydrogen near the ceiling of a room will cause the hydrogen to collect near to the ceiling in dangerous concentrations. This effect can be easily overcome by maintaining a slight circulation of the atmosphere in the room, or by venting the ceilings. This stratification does not occur if the leak is near the floor since the hydrogen readily diffuses through the atmosphere. Where leaks occur in high pressure lines even near ceilings, there is less tendency for stratification to occur because of the mixing action of the jet.

\section{Effect of Chemically Inert Substances}

The addition of increasing amounts of chemically inert substances to mixtures of hydrogen and air causes the upper and lower limits of flammability to approach each other and ultimately to meet. In vessels larger than 2 in. in diam, the effectiveness as a diluent of carbon dioxide, nitrogen, helium and argon decreases in the following order.

$$
\mathrm{CO}_{2} \quad \mathrm{~N}_{2} \quad \mathrm{He} \quad \mathrm{A}
$$

To render any mixture of hydrogen and air harmless, 11 volumes of helium, or 10.2 volumes of $\mathrm{CO}_{2}$ per volume of combustible mixture are required.

Division of Explosives Technology - Bureau of Mines Report \#3543, 9/4/56 


\section{The Limits of Flammability of Hydrogen in Air and Water Vapor}

Water vapor has been shown to be more potent than even $\mathrm{CO}_{2}$ in its extinctive effect on mixtures of hydrogen and air. Whereas, as indicated above, 10.2 volumes of $\mathrm{CU}_{2}$ are required to render $\perp$ volume of any hydrogenair mixture completely non-flammable, on $7 y 7.6$ volumes of water vapor are required to accomplish the same purpose at atmospheric pressure. Experiments carried out over water in a thermostated spherica $\perp$ vesse $\perp$ with mixtures maintained at atmospheric pressure* indicate that the upper and lower flammability limits of hydrogen-air mixtures converge as the percentage of water vapor increases. As the temperature rises and the water vapor content rises as a consequence, the lower limit rises slowly while the upper limit falls rapidly. When approximately 60\% of the hydrogen-air-steam mixture at one atm is composed of steam, the limits coincide at about $10 \%$ hydrogen. The available data for hydrogen-air-steam mixtures at atmospheric pressure are given in Tables 1, 2, and 3. Data for nitrogen and $\mathrm{CO}_{2}$ are included for comparison. The data for hydrogen-steam-air mixtures at $300^{\circ} \mathrm{F}$ and at 0 , as we 11 as 100 psig, are best summarized and compared with the data at standard pressure in the triangular diagram, Fig. 3. It will be noted that there is very little change in the flammability limits in the entire range in which the data were collected.

\section{Spontaneous Ignition Temperature}

\section{Static Systems}

Tests conducted at the Bureau of Mines indicate only a small change in minimum spontane ous ignition temperature with pressure in the range between 0 and 100 psig. As shown in Table 4, minimum spontaneous ignition temperatures of hydrogen-air mixtures vary between only 516 and $523^{\circ} \mathrm{C}$ with the minima occurring at compositions of 30 and $35 \mathrm{v} / 0$ hydrogen. While the progressive addition of water vapor to the hydrogen-air mixtures results in a small increase ( $5 \%$ ) in the minimum sponlaneous iqnition temperature, the resulting depression in the maximum pressure generated during the explosion is quite significant (35\%). The data obtained at an initial pressure of 100 psig are shown in Figs. 4 and 5.

\section{Dynamic Systems}

If hydrogen is passed through a heated pipe into the atmosphere, mixtures are formed which are capable of spontaneous ignition after a period of time depending on the hydrogen temperature and the exit velocity. Although, as indicated previously, the minimum spontaneous ignition temperature under static concitions is $520^{\circ} \mathrm{C} * *$, the minimum hydrogen temperature required to

* J. S. Yeaw and L. Shnidman - A.G.A. Proceedings, Technical Section, pp. $717-745$ (1938)

** In the presence of platinum, surface combustion occurs at temperal ...'s as low as $100^{\circ} \mathrm{C}$. 
effect ignition in the dynami, sxeriments conducted at the Bureau of Mines was approximately $680^{\circ} \mathrm{C}$. Sil an incubation period is observed prior to ignition, of length depending, on gas temperature and flow rate, it is assumed that the ignition occurs after the mixture formed by the hot hydrogen issuing from the pipe contains at least $4.1 \mathrm{v} / 0$ hydrogen, and has achieved a temperature of $520^{\circ} \mathrm{C}$. It is important to note, however, that if a solid object is placed in the path of $1 \mathrm{~lm}$ heated gas, wide diffusion of the hydrogen is apparently prevented and the minimum spontaneous ignition temperature drops from $680^{\circ} \mathrm{C}$ to that observed in the static case, viz, $520^{\circ} \mathrm{C}$. While some variation in the ignition temperature was found with changes in exit velocity, they are relatively small. However, the addition in substantial proportions of water vapor to the hydrogen does raise the minimum spontaneous ignition temperature in a significant manner. These data are summarized in Figs, 6 and 7. 
TABIE $\perp$

\section{EXHLUSIVE LIMITS IN STEAM}

Summary of Experimental Results for Hydrogen

(one atmosphere total pressure)

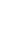

\begin{tabular}{|c|}
\hline $\begin{array}{l}\text { Thermostat } \\
\text { Temp. } \\
{ }^{\circ} \mathrm{F}\end{array}$ \\
\hline $\begin{array}{l}68^{\circ} \\
68^{\circ}\end{array}$ \\
\hline $\begin{array}{l}130 \\
130\end{array}$ \\
\hline
\end{tabular}

150

150

260

160

170

170

180

180

185

185

186

186

187
$\%$ Gas in

Gas-Air

Mixture

72.0

4.7

68.1

5.6

62.7

7.1

58.8

8.0

51.8

10.2

40.7

14.1

30.1

18.0

.28 .0

20.0
$\%$ Steam

Absolute

2.3

15.3

25.7

32.7

41.1

51.5

57.6

58.9

Upper \& Lower

Explosive Limits

\% Gas in Gas-Air-

Steam Mixture

70.3

4.6

57.7

4.7

46.6

5.3

39.6

5.4

30.5

$6 . ?$

19.7

6.8

12.8

7.6

17.5
8.2

no explosion of any nixture 60.1

TABIE 2

The Extinction of Combustible Gas Flames by Inert Gases Minimum Fractions of Inerts in the Inert-Gas-Air Mixtures to Frevent Flame Propagation

Volumes of Inert per \% Inert in Inert- Temperature of

D1EXV uns

Volume of Combustibie

Gas-Air Mixture Mixture ${ }^{\circ} \mathrm{F}$

WitrogenOGEN

Nitrogen

Carbon Dioxide

Water Vapor

16.5

10.2

7.6
71.1

56.5

58.9
75

$75 *$

187

* Calculated 
TABLE 3

\section{THE EXTINCTION OF GAS FLAMES BY INERT GASES}

Minimum Fractions of Inerts in the Inert-Gas Mixtures which are Necessary for the Prevention of Possible Explosive Mixtures Regardless of any Subsequent Dilution with Air*

Inert Gas

Nitrogen

Carbon Dioxide

Water Vapor
Volume of Inert per Volume of Combustible

$$
\begin{array}{r}
16.5 \\
10.2 \\
7.6
\end{array}
$$

\% Inert in Inert- Temperature of Gas Mixture

$$
94.5
$$$$
88.3
$$

75

75

* Assuming no condensation of the steam

TABIE 4

Minimum Spontaneous Ignition Temperatures (S.I.T.) and Maximum Explosion Pressures of Hydrogen-Water Vapor-Air Mixtures in Contact with Stainless Steel (I-33A Apparatus)

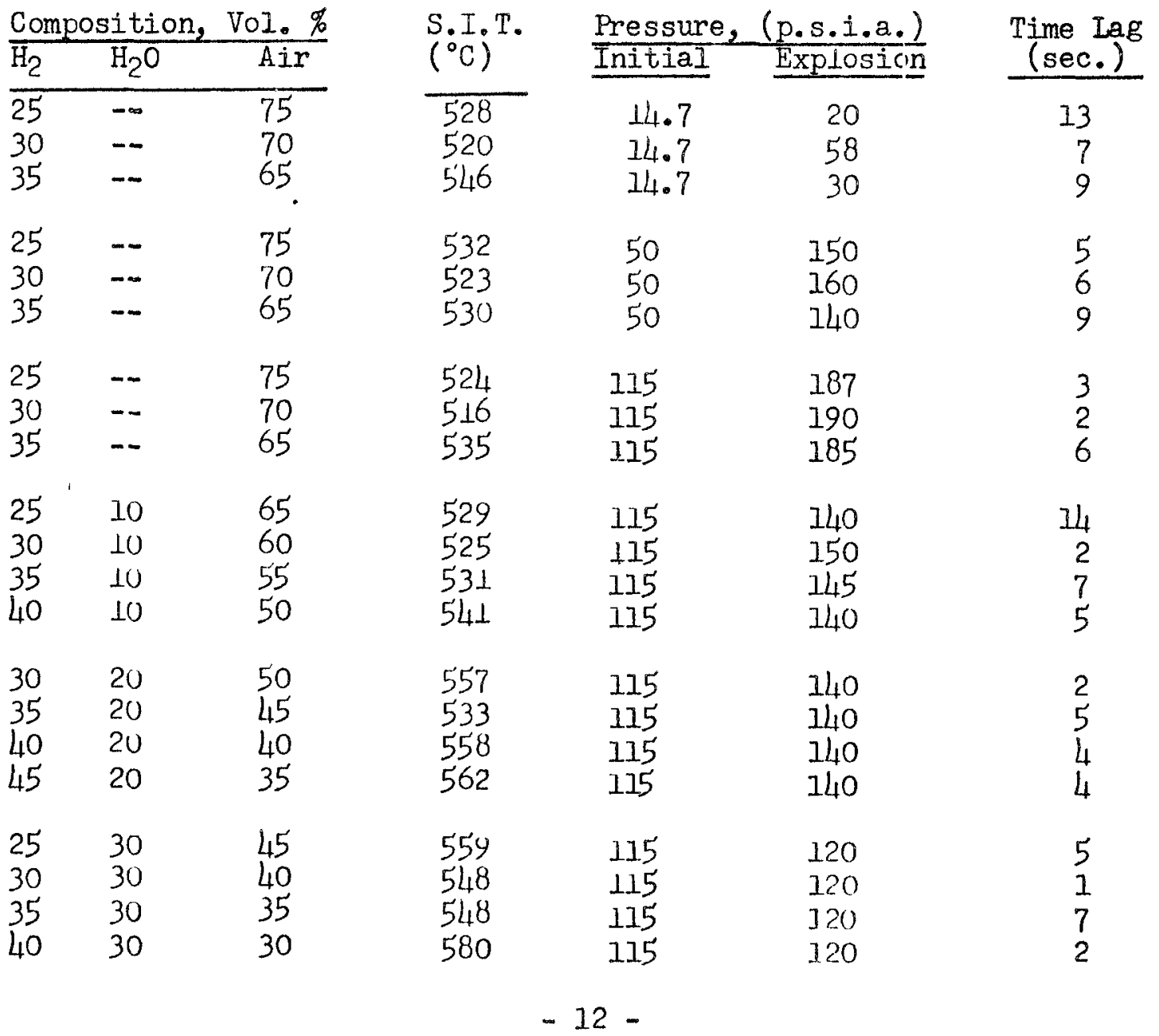


FLAMMABILITY LIMITS OF

\section{HYDROGEN-AIR STEAM MIXTURES}

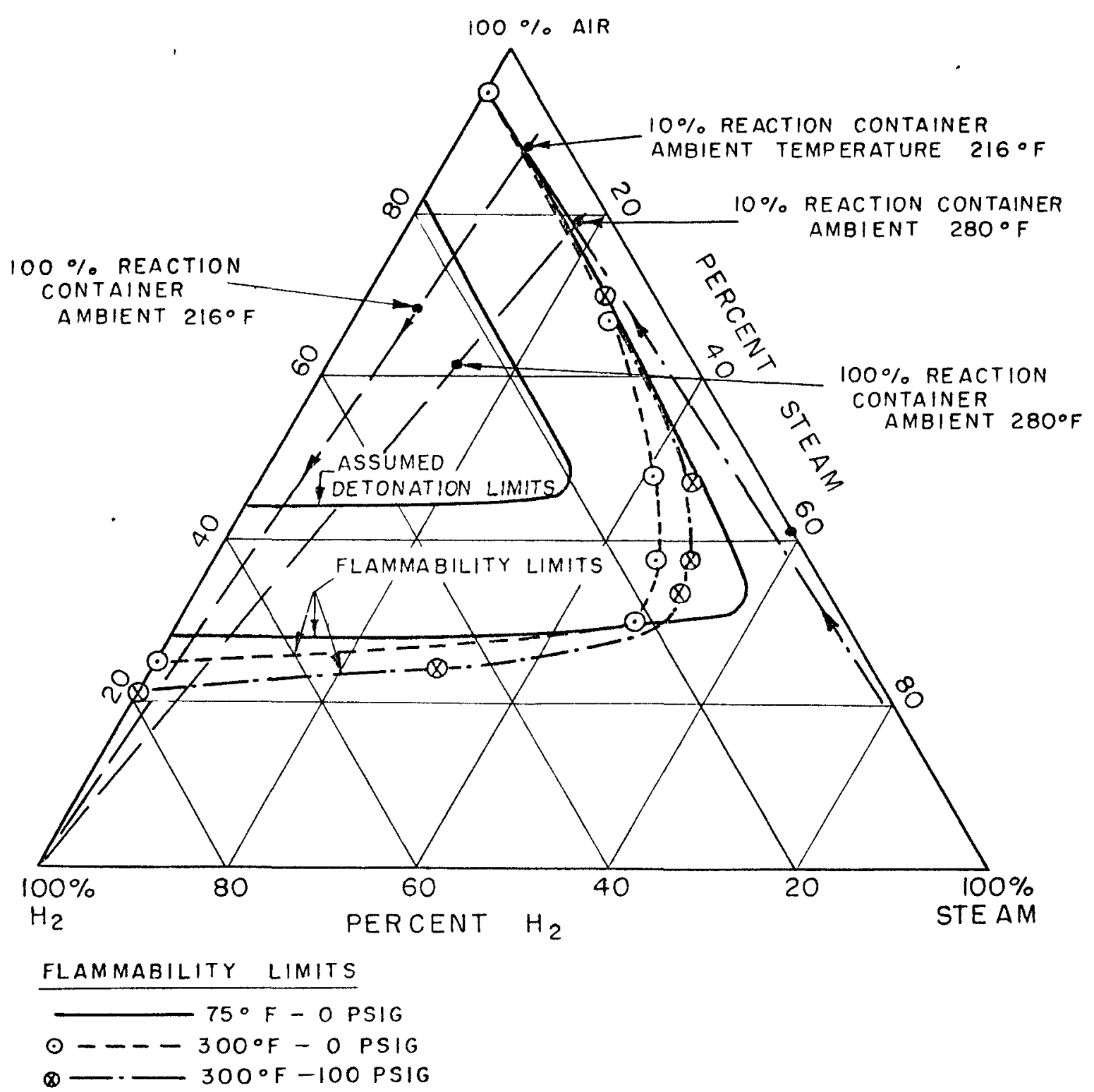

FIG. 3 


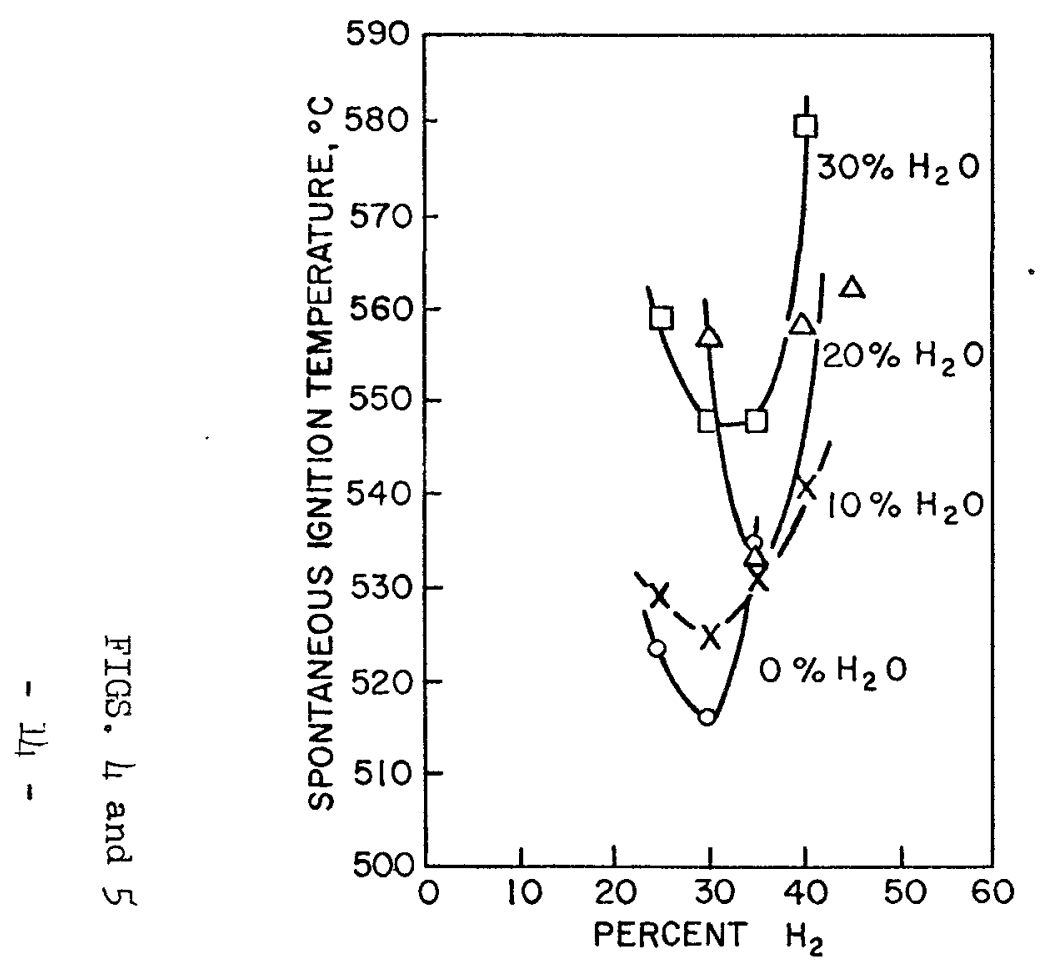

FIGURE 4 - VARIATION IN THE MINIMUM SPONTANEOUS IGNITION TEMPERATURES (S.I.T.) WITH HYDROGEN CONCENTRATION OF HYDROGENWATER VAPOR-AIR MIXTURES CONTAINING $0,10,20$ AND 30 VOLUME PERCENT WATER VAPOR AT IOO P.S.I.G. INITIAL PRESSURE (STAINLESS STEEL APPARATUS.)

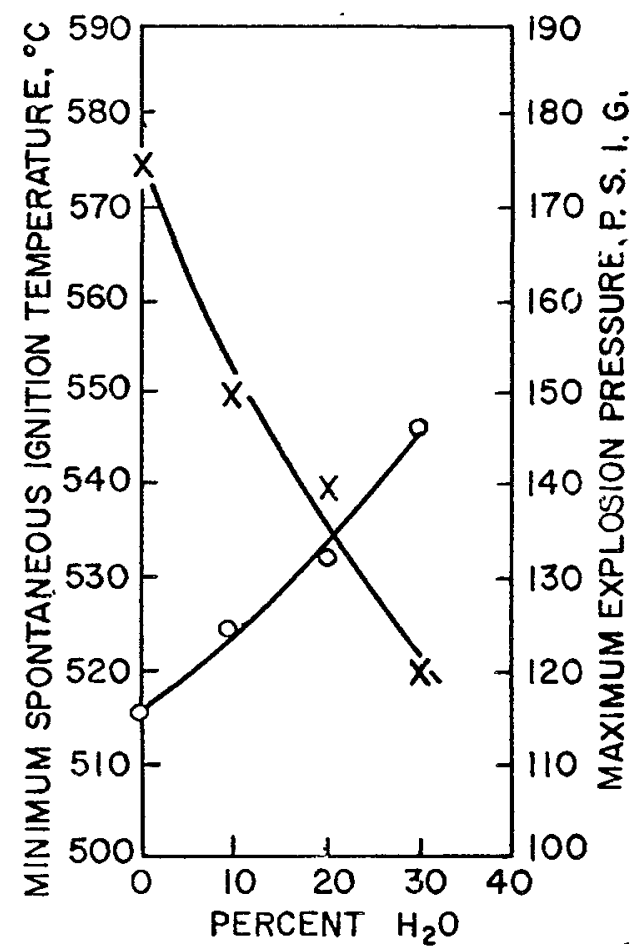

FIGURE 5 - VARIATION IN THE MINIMUM SPONTANEOUS IGNITION TEMPERATURE (S. I. T.) VALUES (O) AND MAXIMUM EXPLOSION PRESSURES (X) WITH WATER VAPOR CONCENTRATION OF HYDROGEN-WATER VAPOR-AIR MIXTURES AT 100 P.S.I.G. INITIAL PRESSURE (STAINLESS STEEL APPARATUS.) 


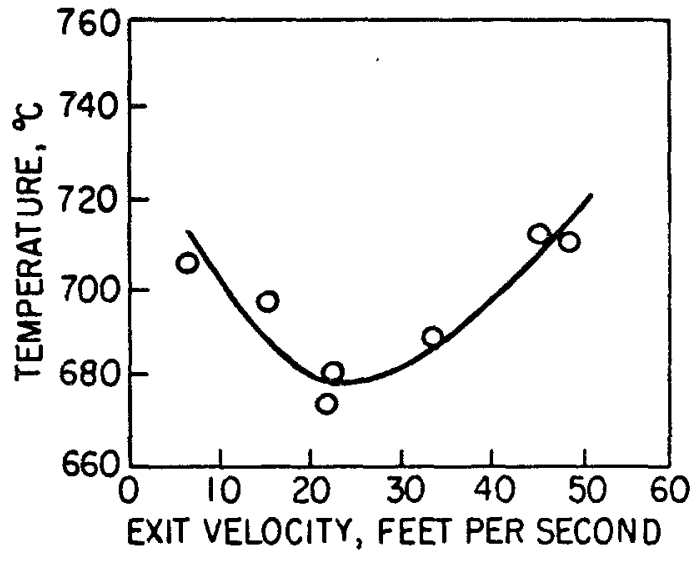

FIGURE 6 - VARIATION IN THE MINIMUM SPONTANEOUS IGNITION TEM PERATURE WITH EXIT VELOCITY OF MYOROGEN FLOWING THROUGH A $0.54-I N C H$ DIAMETER $\times 59-I N C H$ STAINLESS STEEL PIPE INTO UNHEATED AIP. AT ONE ATMOSPHERE PRESS URE

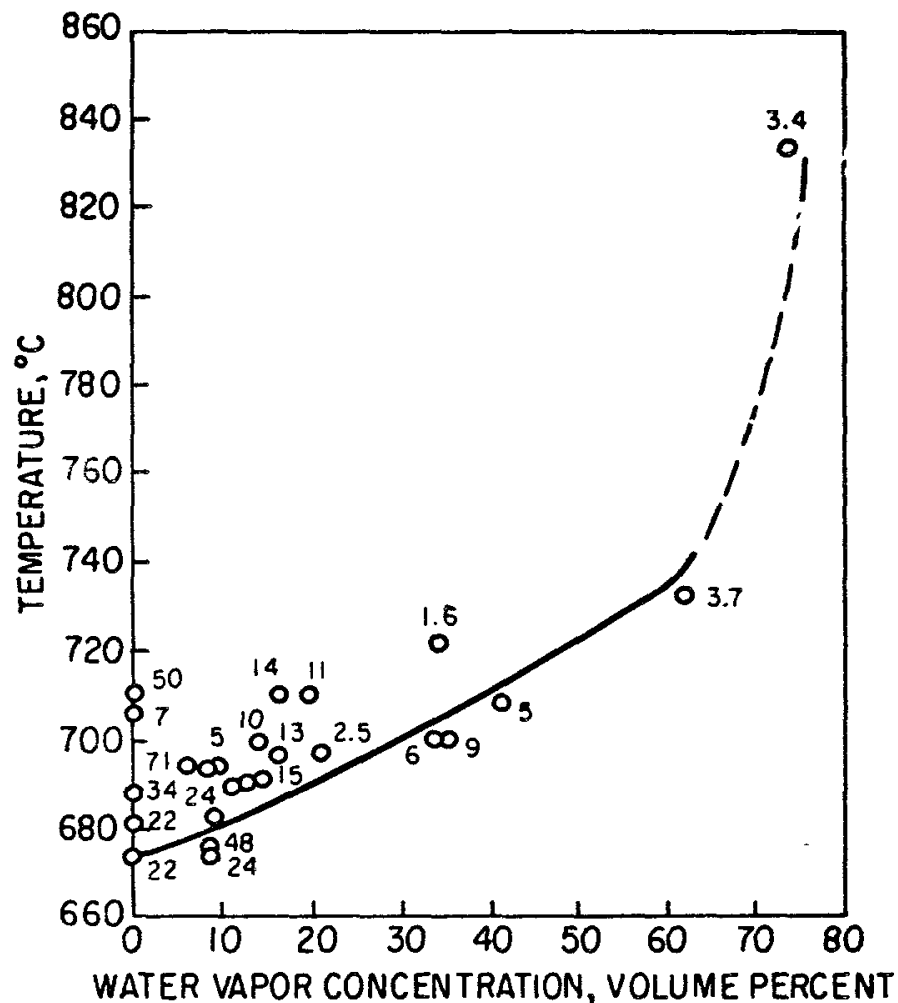

FIGURE 7 - VARIATION IN THE MINIMUM SPONTANEOUS IGNITION TEMPERATURE OF HYOROGEN - WATER VAPOR MIXTURES FLOWING THROUGH A 0.54 INCH DIAMETER X 59-INCH STAINLESS STEEL PIPE INTO UNHEATED AIR AT ONE ATMOSPHERE PRESSURE. (EXIT VELOCITY: 1.6 TO 71 FT. /SEC.) 


\section{APPLICATION TO FWR IOSS-OF-COOLANT ACCIDENT}

A. Combustion of Steam-Hydrogen Mixture Escaping from Rupture as It is Evolved

The preceding generalized discussion indicated that for dynamic systems in which a hydrogen-steam mixture issues from a pipe (the rupture), the minimum spontaneous ignition temperature is $680^{\circ} \mathrm{C}\left(1256^{\circ} \mathrm{F}\right)$. However, if the gas issues against a solid object (as would probably occur with a large rupture of the primary piping within the reactor chamber) the minimum spontane ous ignition temperature drops from $680^{\circ} \mathrm{C}$ to $520^{\circ} \mathrm{C}\left(968^{\circ} \mathrm{F}\right)$. Fig。 20 of WAPD -SC544 indicates the escaping gas will reach the lower spontaneous ignition temperature in $252 \mathrm{sec}$ after the rupture occurs, and the higher spontaneous ignition temperature will be obtained in $260 \mathrm{sec}$. After $200 \mathrm{sec}$ the gas temperature quickly increases a second time, eventually reaching a maximum of $1870^{\circ} \mathrm{F}\left(1020^{\circ} \mathrm{C}\right)$ at $300 \mathrm{sec}$. Unless the gas is cooled before entering the atmosphere of the container (for example, if it should escape from the reactor vessel through a water trap), it appears unlikely that ignition would be delayed after $600 \mathrm{sec}$, and all hydrogen produced after ignition occurred would probably burn as it evolved. The greater portion of the gas would be produced after 600 sec. Therefore, it appears somewhat unlikely that any large amount of unburned hydrogen would accumulate. (The case of unburned hydrogen accumulating is discussed in subsection "B", below)。

The composition of the gas stream escaping from the rupture for the first $1300 \mathrm{sec}$ after the rupture is shown in Fig. 22 of WAPD-SC-544. There it is shown that a $25 \%$ hydrogen and $75 \%$ steam composition is obtained at 600 sec, (when Fig。 20 of WAFD-SC-544 shows the temperature is $1752^{\circ} \mathrm{F}$ or $955^{\circ} \mathrm{C}$ )。 Inspection of Fig。 7 indicates that for hydrogen-steam mixtures issuing from a pipe into air, with a $75 \%$ steam content the minimum spontaneous ignition temperature is about $835^{\circ} \mathrm{C}\left(1535^{\circ} \mathrm{F}\right)$. Therefore ignition of the gas appears assured.

Calculations have been made of the effect on plant container pressure due to burning of the hydrogen gas as it is evolved. Two cases have been calculated and the resulting pressure as shown in Figo 8 within the plant container has been plotted. The first case is one in which the Safety Injection System is assumed not to function, and the maximum zirconium-water reaction and hydrogen production occurs, as calculated in WAPD $\triangle 5 C-544$. The pressure increase within the container is calculated to be less than $5 \mathrm{psi}_{2}$ shown as the upper dashed line of Fig. 8.** The peak total pressure due to the hydrogen combustion is only 24 psig, considerably less than the plant container design pressure of 52.8 psig.

* Repeated in this report for convenience.

** See WAPD-SC-549 "FWR Plant Container Sizing Criteria" for information on

the pressure (and temperature) within the alant container after a large rupture, with no zirconium-water, reaction, as represented by the solid line of Fig. 8 . 

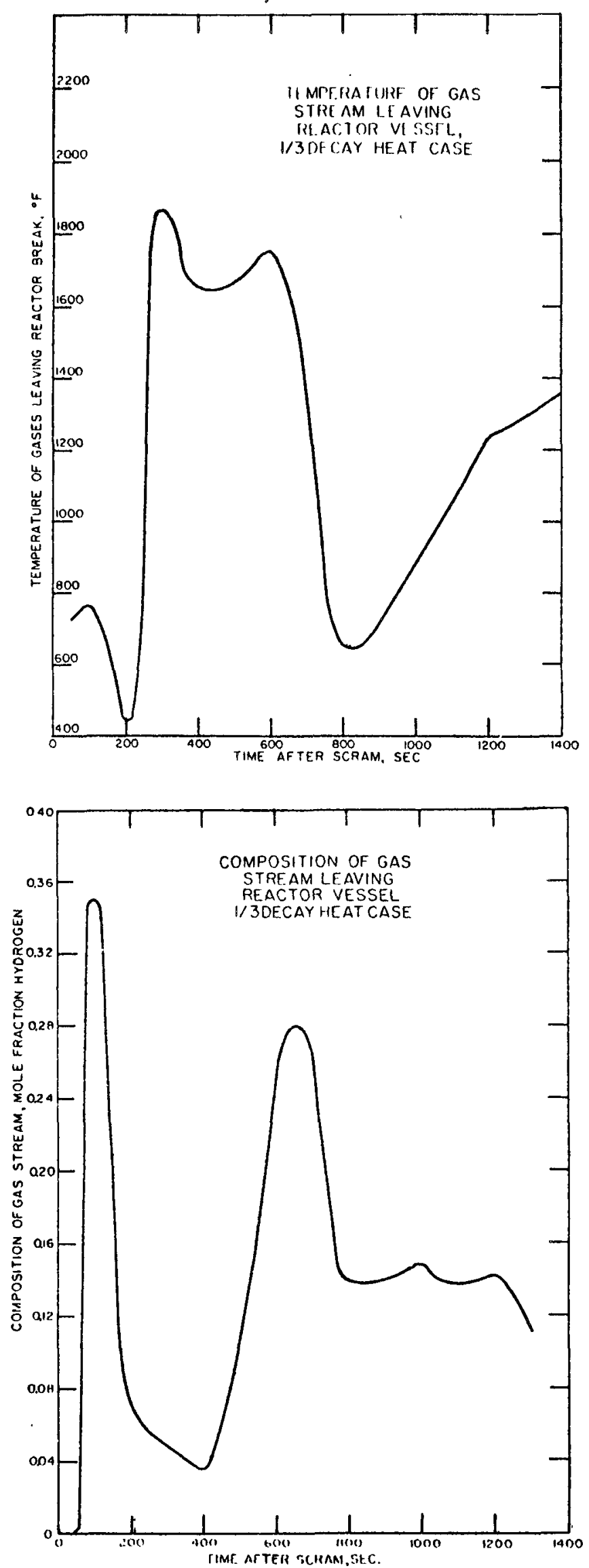

FIGURES 20 AND 22 UF WAPD-SC-54'4 (Repeated here for convenience) TEMPERATURE AND COMPOSITION OF UAS STRFAM IEAAVING REACTOR VESSEL 


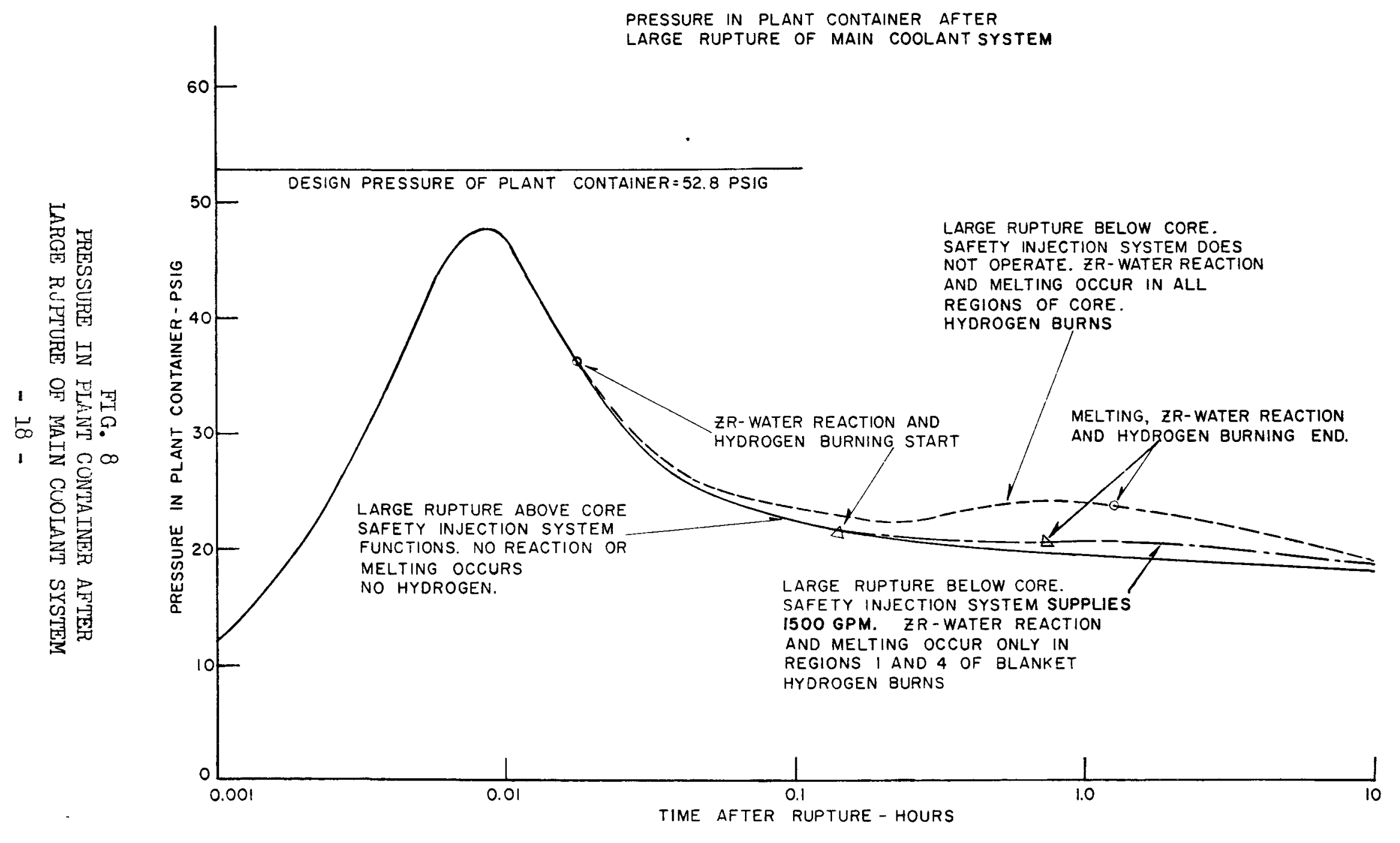


The second case calculated is one in which the Safety Injection System is assumed to function, but at its minimum output of $1500 \mathrm{gpm}$. Considerably less zirconium-water reactor and hydrogen production occurs, and as shown in Fig. 8, the pressure rise within the plant container is less severe than the former case.

While there appears to be no danger to the plant container due to overpressure under the above conditions, the possibility of damage to the container caused by localized high temperatures in the region of combustion is extremely difficult to assess. This is due to the many unknowns to be considered in such a postulated accident, such as the exact location of a rupture.

\section{B. Delayed Combustion of Accumulated Hydrogen}

In case the hydrogen does not burn as it is evolved and escapes from the rupture (for example if it should escape from the reactor vessel through a water trap with resulting cooling of the gas), it is necessary to investigate the possibility of detonation of the accumulated hydrogen。

From the worst case accident investigated in WAPD-SC-544, it can be calculated that $3095 \mathrm{Ib}$ or $16.5 \%$ of the active zirconium in the core might react exothermically with steam or water, and producing $67.75 \mathrm{lb}$-moles of hydrogen, At standard conditions the hydrogen would occupy $24,330 \mathrm{cu} \mathrm{ft}$. If the hydrogen is assumed to mix uniformly with the steam and air in the plant container, the possibility of burning or detonation may be determined by referring to Figs. 3 and 9 . By comparison with the $10 \%$ reaction case in Fig. 3 , it may be seen that $a 16.5 \%$ reaction would make a mixture slightly inside or at the limit of the flammable region, depending on the temperature and the resulting fraction of steam in the mixture.

Fig. 9 is a simplification of Fig. 3, using only the flamability and detonation limits at $75^{\circ} \mathrm{F}$, and applied specifically to the PWR loss of coolant accident. Two cases are presented in Fig. 9, one in which 45,000 cu ft of air have been swept out of the container by steam escaping from the rupture before the plant container ventilation system butterfly valves close, leaving $430,000 \mathrm{cu}$ ft of air (at standard conditions) within the closed container. In the second case it is assumed the container is sealed at the time of rupture and no air escapes, leaving the entire container net free volume of 475,000 $\mathrm{cu} \mathrm{ft}$ of air. There is no significant difference between the two cases in regards to the specific accident considered here. Here again it is seen that the maximum calculated reaction of $16.5 \%$ of the zirconium would produce only enough hydrogen for the air-steam-hydrogen mixture to enter the lower limit of the flamable region. If such a weak mixture should become ignited, only about $50 \%$ of the hydrogen would burn, and the energy release would be reduced accordingly, as previously mentioned in Sec. I-B-1. The pressure peak would not be expected to exceed the plant container design pressure, considering the data of Table 4 and the lean mixture. 


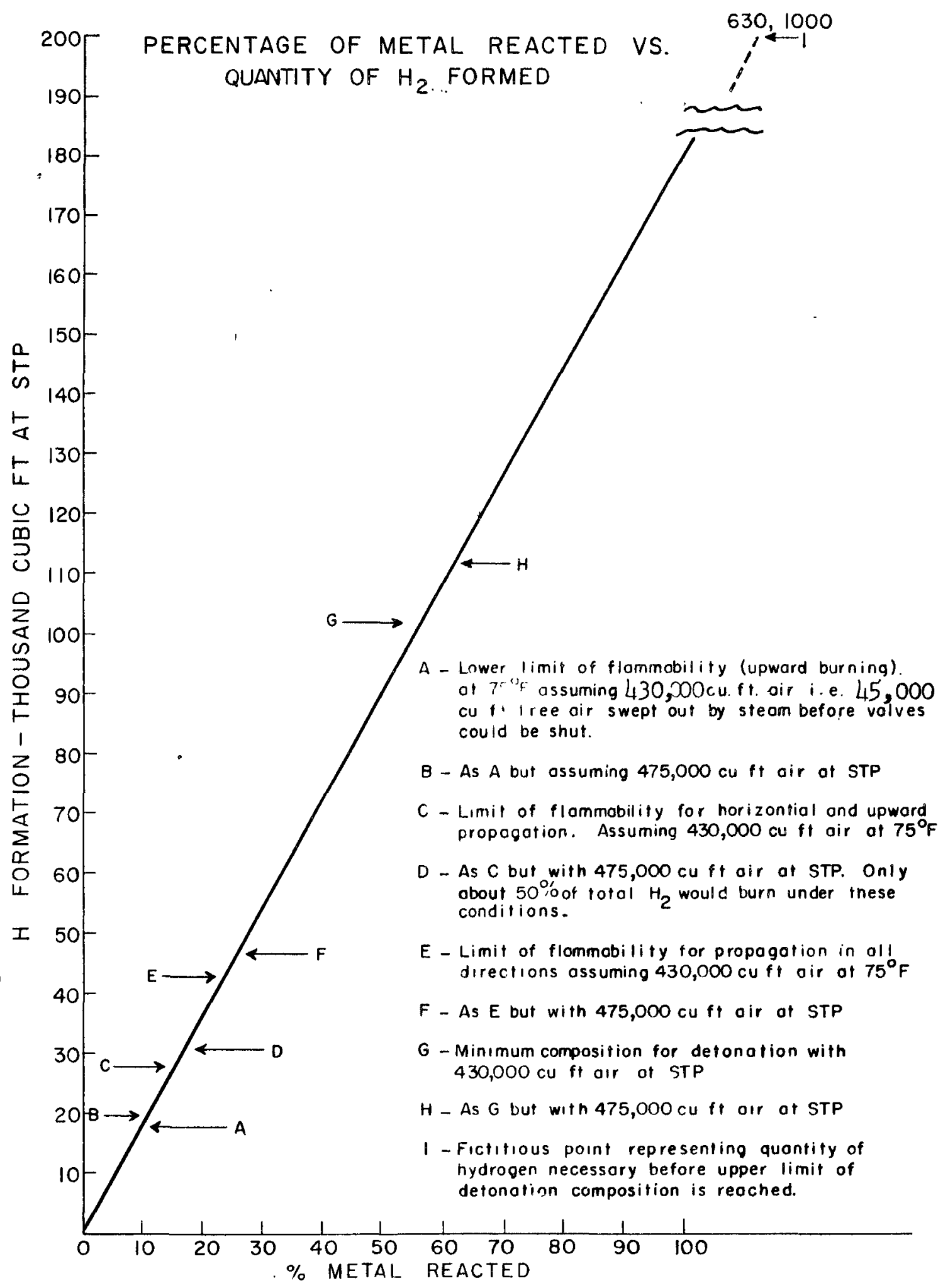

FIG. 9 
Approximately four times the $16.5 \%$ reaction would be required to produce enough hydrogen to permit detonation, assuming a uniform mixture.

Another case has been calculated involving operation of the Safety Injection System at its minimum expected output of $1500 \mathrm{gpm}$ of cooling water to the core, with melting and zirconium-water reaction limited to regions one and four of the blanket. The maximum zirconium-water reaction involves only 4.5\% of the zirconium in the core, considerably less than the case previously considerea. By reference to Fig. 9 it may be seen that, if uniformly mixed, the hydrogen product $c$ f $4.5 \%$ zirconium reaction would be insufficient to bring the mixture within the Ilammable limit. Therefore, if the gas is not burned as it is evolved, and if it is uniformly mixed, neither burning nor detonation should occur.

For either of the above cases, however, the multivessel compartmented plant container might hinder uniform mixing of the hydrogen, air, and steam. Local pockets with high concentrations of hydrogen may occur, causing an explosion hazard in that region.

If an explosion occurs, the $475,000 \mathrm{cu}$ ft net volume of the container would cushion the over-all shock considerably. Data on the maximum explosion pressures of hydrogen-air-steam mixtures given in Table 4 indicate the resulting pressure rise should be comparatively slight, due to the presence of steam in the atmosphere. The pressure in the plant container would be less than 24 psig before an explosion, so the peak pressure would not be expected to exceed the plant container design pressure of 52.8 psig.

C. Vacuum Due to Combustion of Hydrogen

After the atmosphere within the container cools and the steam condenses, the internal pressure will be reduced below the initial pressure in proportion to the amount of oxygen or air consumed, creating a partial vacuum. The plant container is designed to withstand an external pressure (internal vacuum) of 3 psi.

The calculated maximum amount of hydrogen that could be produced as a result of the loss-of-coolant accident and a subsequent zirconium-water reaction is 67.75 Ib-moles, as mentioned above in Section B. Combustion of all of the hydrogen would consume $33.9 \mathrm{lb}$-moles of oxygen, or $12,180 \mathrm{cu}$ ft at standard conditions.

Assuming none of the $475,000 \mathrm{cu}$ ft of air in the plant container escapes before the ventilation system butterfly valves close at the start of the accident, the combustion of $12,180 \mathrm{cu}$ ft of oxygen would cause a $0.4 \mathrm{psi}$ vacuum after the steam condensed. 
Should as much as $45,000 \mathrm{cu}$ ft of air escape before the butterfly valves close, and with the combustion of $12,180 \mathrm{cu}$ ft of oxygen, the final pressure within the container would be only 1.7 psi below atmospheric pressure.

It is concluded that the postulated accident will not cause the external pressure on (internal vacum in) the plant container to exceed the design differential of 3 psi. 
KEFERENCES

The information presented in Section I was taken largely from the following documents:

1. Bureau of Mines Bulletin 503, Limits of Flammability of Gases and Vapors, by H. F. Coward and G. W. Jones.

2. A paper by J. S. Yeaw and I. Shinidman entitled "The Extinction of Gas Flames by Steam" found in the Technical Section of A.G.A. rroceelings for 1938, pp. 717-145.

3. Division of Explosives Technology, Bureau of Mines Report No. 3543, September 4, 1956, by M. G. Zabetakis. 